\title{
Thrombosis in Arterial and Venous System Simultaneously; What is the Reason?
}

\author{
Arteryal ve Venöz Sistemde Eş Zamanlı Gelişen Tromboz; Nedeni Ne Olabilir?
}

İnan Beydilli, Nalan Kozacı, Faruk Güngör, Asım Arı

Clinic of Emergency Medicine, Antalya Training and Research Hospital, Antalya, Turkey

\section{ABSTRACT}

Introduction:Thrombophilia is a hemostatic disorder that defined as a tendency to thrombosis. It can be hereditary and acquired. Hereditary thrombophilia is responsible for approximately $40 \%$ of all thrombotic events.

Case Report: Factor $v$ Leiden mutation is the most common hereditary disorder in patients with venous thromboembolism. Other genetic disorders seen more common are prothrombin G20210A mutation, protein C deficiency, protein S deficiency, antithrombin III deficiency and hiperhomosistinemia. The patients with acquired thrombophilia are prone to venous thrombosis, whereas in the patients with genetic thrombophilia both arterial and venous thrombosis can be seen.

Conclusion: In this article we discussed a case with simultaneously arterial and venous thromboembolism in patient with protein C and protein S deficiency.

Keywords: Thromboembolism, thrombophilia Received: 02.09.2013 Accepted:29.12.2013

\section{ÖZET}

Giriş: Trombofili hemostatik mekanizmalardaki bozukluk olup trombozise eğilim olarak tanımlanır. Herediter ve akkiz nedenli olabilir. Tüm tromboz olaylarının yaklaşık \%40'ında herediter trombofililer sorumlu tutulmaktadır.

Olgu Sunumu: Tromboembolik olgularda en sık görülen herediter bozukluk faktör $V$ Leiden mutasyonudur. Sık görülen diğer kalıtsal risk faktörleri ise protrombin G20210A mutasyonu, protein C eksikliği, protein S eksikliği, antitrombin III eksikliği, hiperhomosistinemidir. Kalıtsal trombofilisi olan hastalar venöz tromboza yatkındır oysaki edinsel bozukluğu olan hastalarda arteryal ve venöz pıhtının her ikisi de görülür.

Sonuç: Biz bu makalede hem arterial sistemde hem de venöz sistemde eş zamanlı emboli tespit edilen ve edinsel protein $C$ ve S eksikliği saptanan bir olguyu tartıştık.

Anahtar Kelimeler: Tromboemboli, trombofili

Geliş Tarihi: 02.09.2013 Kabul Tarihi: 29.12.2013

\section{Giriş}

Trombofili hemostatik mekanizmalardaki bozukluk olup trombozise eğilim olarak tanımlanır. Herediter ve akkiz nedenli olabilir. Tüm tromboz olaylarının yaklasık \%40'ında herediter trombofililer sorumlu tutulmaktadır. Tromboembolik olgularda en sık görülen herediter bozukluk faktör V Leiden mutasyonudur. Sık görülen diğer kalıtsal risk faktörleri ise protrombin G20210A mutasyonu, protein C eksikliği, protein S eksikliği, antitrombin III eksikliği, hiperhomosistinemidir. Kalıtsal trombofilisi olan hastalar venöz tromboza yatkındır oysaki edinsel bozukluğu olan hastalarda arteryal ve venöz pıhtının her ikisi de görülür.

Biz bu makalede hem arterial sistemde hem de venöz sistemde eş zamanlı emboli tespit edilen ve edinsel protein C ve S eksikliği saptanan bir olguyu tartıştık.

\section{Olgu Sunumu}

Yetmiş üç yaşında kadın hasta 2 gündür devam eden sırta vuran karın ağrısı, nefes darlığı, bulantı ve kusma şikayetleri ile acil servisimize başvurdu. Hastanın özgeçmişinde diabetes mellitus ve hipertansiyon olduğu ve oral antidiabetik (glimax@ 2mg) ile ACEl (anjiotensin-konverting enzim inhibitörü), (delix plus@) kullandığı öğrenildi. Hastanın yapılan fizik muayenesinde 


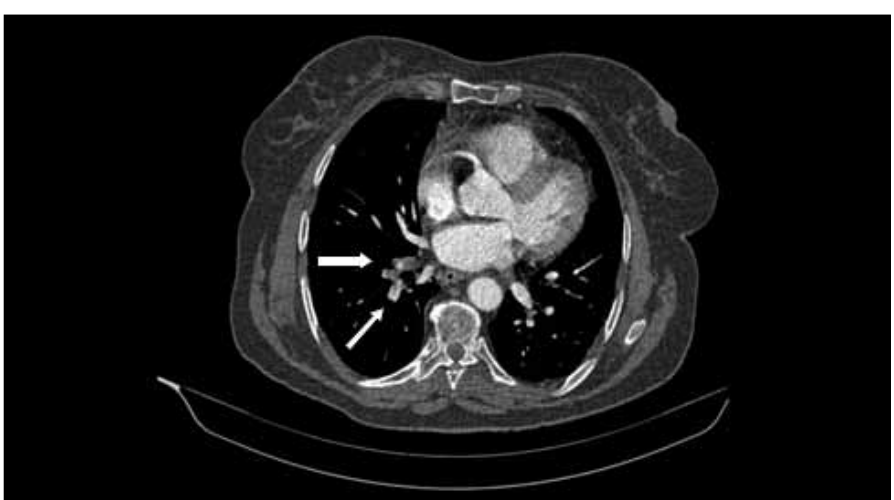

Şekil 1. Sağ pulmoner arter alt lob segmental ve subsegmental dallarda yaygın emboli ile uyumlu görünüm

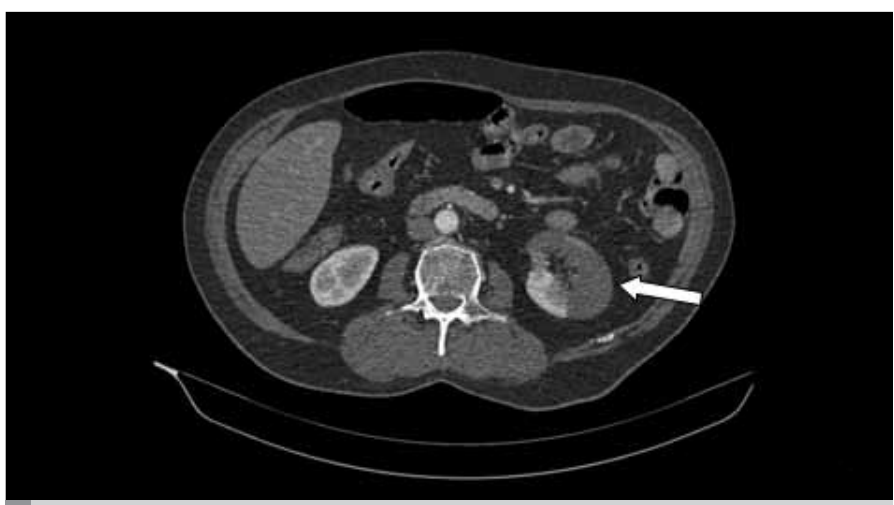

Şekil 2. Sol böbrek alt kesiminde infarkt görünümü

genel durumu orta, şuuru açık, oryante, koopere idi. Vital bulguları kan basıncı; 200/100 mmHg, nabız 100/dk, solunum sayısı; 28/ dk, O satürasyonu; \%92 ve vücut sıcaklığı 37,3ㄷ ölçüldü. Batın muayenesinde defans ve yaygın hassasiyet mevcuttu. Diğer sistem muayeneleri doğaldı. İdrar çıkışı mevcuttu. Elektrokardiyografisinde sinüs ritmi, hız:102/dk ve sol dal bloğu tespit edildi. Laboratuar çalışmalarında beyaz küre 14,0 K/uL (4,0-11,0 K/uL), hemoglobin $14,5 \mathrm{gr} / \mathrm{dL}(12-17 \mathrm{gr} / \mathrm{dL})$, trombosit $260 \mathrm{~K} / \mathrm{uL}$ (150-450 K/uL), glukoz $305 \mathrm{mg} / \mathrm{dL}$ (70-110mg/dL), BUN $44 \mathrm{mg} / \mathrm{dL}$ (8-20 mg/dL), kreatinin 1,7 mg/dL (0,6-1,2 mg/dL), Na: 129 mmol/L (135-145 mmol/L), ALT $21 \mathrm{U} / \mathrm{L}(0-50 \mathrm{U} / \mathrm{L})$, d-dimer $1256 \mathrm{ng} / \mathrm{dl}$ (0-250), Tam idrar tahlilinde pH: 6,0, dansite: 1,013, eritrosit (+), glukoz: (+), lökosit (-) idi. Arterial kan gazında PH: 7.46, $\mathrm{PO}_{2}: 57,6, \mathrm{PCO}_{2}: 33,1, \mathrm{HCO}_{3}: 22 \mathrm{mEq} / \mathrm{L}, \mathrm{BE}: 2,4$ saptandı. Çekilen akciğer grafisinde; diyafram normal konumda, sinüsler açık olarak izlendi. Kalp tepe oranı (KTO) normal, hiluslar normal konumda ve büyüklükteydi. Sağ alt zonda bant tarzında homojen gölge koyuluğu ve parakardiyak alanda dallanma artışı mevcuttu. Diğer parankim alanlarında aktif patoloji gözlenmedi. Batın ultrasonografisi normal olarak değerlendirildi. Ekokardiyografisinde sağ kalp boşluğunda dilatasyon tespit edildi, pulmoner arter basıncı $55 \mathrm{~mm} / \mathrm{Hg}$ olarak hesaplandı.

Mevcut bulgular ile hastada pulmoner emboli (PE) düşünüldü. Tanıyı desteklemeye yönelik kontraslı spiral toraks bilgisayarlı tomografisi (sBT) ve alt ekstremite venöz doppler ultrasonografi (USG) (Esaote,
Tablo 1. Koagülasyon sonuçları (emboli tedavisi sırasında)

\begin{tabular}{|lcc|}
\hline Tetkik adı & Sonuç (\%) & Referans aralık (\%) \\
\hline Antitrombin III aktivitesi & 84.4 & $75-125$ \\
\hline Faktör V & 128,7 & $40-150$ \\
\hline Protein C & $\mathrm{L} 19,6$ & $70-140$ \\
\hline Protein S & $\mathrm{L} 47,8$ & $60-130$ \\
\hline
\end{tabular}

Tablo 2. Koagülasyon sonuçları (kontrol)

\begin{tabular}{|lcc|}
\hline Tetkik adı & Sonuç (\%) & Referans aralık (\%) \\
\hline Antitrombin III aktivitesi & 98,3 & $75-125$ \\
\hline Faktör V & 136,8 & $40-150$ \\
\hline Protein C & 92,6 & $70-140$ \\
\hline Protein S & 111,2 & $60-130$ \\
\hline
\end{tabular}

Mylab Class-C, Italy) yapıldı. Ek olarak hastada akut karın bulguları olması nedeni ile intravenöz kontraslı batın BT de çekildi (Siemens SOMATOM Emotion 16 CT Scanner, German). Alt ekstremite doppler USG sonucunda venöz ve arteryal akım paternleri normal olarak değerlendirildi. Çekilen toraks ve batın BT'sinde (Siemens SOMATOM Emotion 16 CT Scanner, German) sağ pulmoner arter alt lob segmental ve subsegmental dallarda yaygın emboli ile uyumlu hipodens alanlar ve sol böbrek alt kesiminde arteryal fazda kontrastlanma eksikliğinin olduğu (infarkt) (Şekil 1-2) alanlar tespit edildi. Hasta yoğun bakım ünitesine tedavi için yatırıldı. Hastada yatışı sırasında antitorombin III, faktör V, VII, VIII, IX, Protein C ve S düzeyleri çalışıldı (Tablo 1).

Hastanın tedavisine yönelik düşük molekül ağırlıklı heparin başlandı. Takiplerinde hastanın klinik bulguları düzeldi. Hastanede yattığı süre içinde ek problem gelişmedi. On sekiz gün sonunda taburculukta hastanın kalıtsal koagülasyon bozuklukları tekrar değerlendirildi (Tablo 2).

Bu değerlerin normal sınırlarda olduğu gözlendi. Hastaya $5 \mathrm{mg}$ warfarin peroral (P.O.) tedavisi başlandı. Klinik takibinde bulguları düzelen hasta warfarin 5 mg. P.O. ve INR kontrolü önerilerek taburcu edildi.

\section{Tartışma}

Derin ven trombozu, pulmoner emboli gibi damar içi tromboza bağlı bir rahatsızlık nedeni ile acil servise başvuran hastada trombofili düşünülmelidir. Her ne kadar venöz tromboemboli (VTE) patogenezi halen tam olarak açıkığa kavuşmamışsa da olayın genetik ve çevresel faktörlerin karmaşık ilişkisi ile ortaya çıktığı bilinmektedir. VTE için kabul edilen risk faktörleri; kalıtımsal veya kazanılmış olarak sınıflanabilir $(1,2)$.

Genç yaşta tromboz gelişen, tekrarlayan venöz trombozu bulunan, tromboz için pozitif aile hikayesi olan, arteryel tromboz, heparin direnci, warfarin ile indüklenen deri nekrozu, östrojen kullanımı ve gebelik sırasında tromboz gelişen hastalarda kalıtsal risk faktörlerinin 
araştırılması önerilmektedir (3). Ayrıca genç yaşta miyokard enfarktüsü, serebral venöz sinüs trombozu ve akut serebrovasküler olayda düşünülmelidir. Bu amaçla bu hasta grubunda faktör V Leiden ve protrombin G20210A mutasyonları, protein C, protein $S$, antitrombin III ve homosistein araştırılmalıdır. Kalıtsal tromboz tanısının doğru konulabilmesi için tetkiklerin çalışılma zamanı ve bunları etkileyen faktörlerin bilinmesi gerekmektedir $(4,5)$.

Illeri yaş, uzun süreli immobilizasyon, cerrahi, travma, oral kontraseptif (OK), hormon replasman tedavisi, gebelik, puerperium, kanser, antifosfolipid sendromu kazanılmış risk faktörlerini oluşturur. Bu durumlar tek başlarına tromboza yol açabilirler, ek olarak kalıtımsal trombofililerde tetikleyici mekanizmayı oluşturabilirler (1, 4). Bununla birlikte damar içi tromboz oluşumları damar duvarı yaralanmaları, lokal inflamasyon ya da vasküler staz gibi tromboembolik olayları başlatan lokal durumlara bağlı olabilir (5).

Trombofili araştırılan kişilerde ileri testler yapılırken göz önüne alınması gereken önemli bir kural olarak protein C (PC), Protein S (PS) ve antitrombin III eksiklikleri için antijen düzey tayininden çok fonksiyonel aktivite ölçülmelidir, çünkü plazma konsantrasyonu normalken, fonksiyonel aktivite düşük olabilir (6). Ayrıca Faktör 8 düzeyi trombotik olaydan en az altı ay sonra (faktör 8 akut faz reaktanıdır) ve antikoagülan tedavi kullanımazken yapılmalıdır. Protein C düzeyleri de benzer şekilde akut tromboz sırasında değerlendirildiğinde düşük değerler elde edilir (7). Bu nedenle bu testlerin tekrarı önemlidir. Literatürdeki kısıtlı bilgiler nedeni ile faktör 9, 10, 11'in genelde rutin olarak çalışması önerilmez (1).

Günümüzde, Aktive protein C rezistansı (APC-R) kalıtsal tromboz sebeplerinin en sık görülenidir. APC-R vakalarının \%90-95'inde faktör $V$ Leiden (FVL) mutasyonu mevcuttur $(5,6)$. Asemptomatik Protein C eksikliği kalıtımsal ve akkiz olarak görülmektedir. Kalıtımsal Protein C eksikliği heterozigot veya homozigot olup her iki şekilde otozomal dominant geçişlidir (7). Heterozigot protein C eksikliği olan hastaların çok azında genç yaşlarda trombotik komplikasyonlar gelişir ve genellikle yaşamları boyunca asemptomatik kalırlar. Homozigot protein C eksikliğinde ise klinik semptomlar daha şiddetli olduğundan erken yaşlarda ölüm ile sonuçlanabilir (7,8). Akkiz protein C eksikliği karaciğer hastalıklarında, dissemine intravasküler koagülasyonda, L-asparaginaz veya kumadin tedavileri sonrasında, akut şiddetli bakteriyel ve viral infeksiyonlarda gelisebilir (2).

Protein S (PS) önemli bir antikoagülan proteindir. Faktör Va ve VIIla'nın inaktivasyonu işleminde aktif protein C (APC)'nin nonenzimatik kofaktörü rolünü oynamasının yanı sıra APC'den bağımsız olarak da antikoagülan aktivite gösterir. Bu nedenle PS eksikliği tromboz oluşumu için önemli bir risk faktörüdür (1). Kalıtsal protein S eksikliğinin yanında neonatal dönem, gebelik, karaciğer hastalığı, dissemine intravasküler koagülasyon, nefrotik sendrom, warfarin, östrojen, L-asparaginaz kullanımı kazanılmış protein S eksikliğine neden olabilmektedir $(8,9)$. Akut trombotik durumlarda da protein $\mathrm{S}$ düzeylerinde azalma olmaktadır. Bu nedenle protein S düzeyleri akut trombotik olaydan sonra ve düşük molekül ağırlıklı heparin tedavisi alırken çalışımalıdır (5).

Sunulan olguda hem arteryel hem de venöz sistemde eş zamanlı emboli tespit edildi. Hastanın akut dönemde bakılan protein $C$ ve $S$ düzeyleri düşük bulundu. Bu düşüklük akut trombotik olaya bağlandı. Hastanın taburcu olduğu gün (18. gün) bakılan koagülasyon parametrelerinin normal sınırlarda olduğu gözlendi. Hastaya warfarin tedavisi başlandığı için kontrol muayenelerinde protein $C$ ve $S$ düzeyleri tekrar ölçülmedi. Bu sonuçlarla birlikte hastanın özgeçmişinde tromboembolik bir hadisenin gelişmemiş olması bizi kalıtsal protein C ve S eksikliğinden uzaklaştırdı. Bu hastada tromboz nedeni hastanın ileri yaşta olması, embolinin eş zamanlı hem arter hem venöz sistemde oluşmasına bağlı olarak ileri yaşa bağlı vasküler yapı bozukluğuna bağlandı.

\section{Sonuç}

Antikoagulan protein düzeylerinin düşük bulunması her zaman kalıtsal trombofilileri düşündürmemelidir. Akut trombotik hadise sırasında antikoagülan düzeyleri değişebilmektedir. Bu nedenle kalıtsal trombofili varlığını ortaya koymak için bu testler hastanın sağlıklı iken ve antikoagülan protein düzeylerini etkileyen herhangi bir ilaç kullanmadığı dönemde (örneğin warfarin gibi) yapılmalıdır.

Informed Consent: Written informed consent was obtained from patient who participated in this case.

Peer review: Externally peer-reviewed.

Author contributions: Concept - I.B.; Design - F.G.; Supervision - F.G.; Materials - I.B.; Data Collection and/or Processing - N.K.; Analysis and/ or Interpretation - N.K.; Literature Review - A.A.; Writer - N.K.; Critical Review - F.G.

Conflict of interest: The authors declared no conflict of interest.

Financial Disclosure: The authors declared that this study has received no financial support.

Hasta Onamı: Yazılı hasta onamı bu olguya katılan hastadan alınmıştır.

Hakem değerlendirmesi: Dış bağımsız.

Yazar Katkıları: Fikir - I.B.; Tasarım - F.G.; Denetleme - F.G.; Malzemeler I.B.; Veri toplanması ve/veya işlemesi - N.K.; Analiz ve/veya yorum - N.K.; Literatür taraması - A.A.; Yazıyı yazan - N.K.; Eleştirel İnceleme - F.G.

Çıkar Çatışması: Yazarlar çıkar çatışması bildirmemişlerdir.

Finansal Destek: Yazarlar bu çalışma için finansal destek almadıklarını beyan etmişlerdir.

\section{Kaynaklar}

1. Oner F, Kaya A, Doğan R, Numanoğlu N. Venöz Tromboembolizmde Kalıtsal Risk Faktörleri. Tüberküloz ve Toraks Dergisi. 2003; 51: 60-9. 
2. Gedik E, Girgin S, Senem S, Taçyıldız I.H, Keleş C. Protein C eksikliğine bağlı mezenter ven trombozu: dört olgu. ADÜTıp Fakültesi Dergisi. 2009; 10: 37-40.

3. Yokuş O., Şahin Balçık O., Albayrak M., Ceran F., Dağdaş S., Yılmaz M. et al. Evaluation of risk factors for thrombophilia in patients with cerebral venous thrombosis. Turk J Hematol. 2010; 27: 162-7. [CrossRef]

4. Stephen J,C., Robin R. Hemphill.Tests of Hemostasis .In Judith E. Tintinally, MD, MS, Editor. Emergency Medicine. 7th ed. New York: McGraw-Hill; 2010. p.3922-3927.

5. Akbal E, Koca D, Altınbaş M. A Case of Arterial Embolism in Upper and Lower Extremities in a Patient with Factor $\vee$ Leiden Mutation and Pseudoprotein S Deficiency. Erciyes Medical Journal. 2009;31: 344-48.

6. Uçar N, A. Dursun B, Alpar S, Karakaya T, Kurt B. Protein C, Protein S Eksikliği, Aktive Protein C Rezistansı ve Faktör $V$ Leiden Mutasyonuna
Bağlı Tekrarlayan Pulmoner Tromboemboli Olgusu. Solunum Hastalıkları. 2005; 16: 90-4.

7. Ben Romdhane N, Baccouche H, Ammar S, Mahjoub S, Chabrak S. Protein S, C and antithrombin deficiency: association with myocardial infarction and thromboembolism in the young. Tunis Med. 2012; 90: 316-9.

8. Ikejiri M, Shindo A, li Y, Tomimoto H, Yamada N, Matsumoto $T$, et al. Frequent association of thrombophilia in cerebral venous sinus thrombosis. Int J Hematol. 2012; 95: 257-62. [CrossRef]

9. Yokuş O, Şahin Balçık Ö, Albayrak M, Ceran F, Yılmaz M, Dağdaş S, et al. Thrombophilic risk factors in women with recurrent abortion. Journal of Clinical and Experimental Investigations. 2010; 1: 168-72. [CrossRef] 